\title{
An Economic Comparative Assessment using Mi-2 Helicopter and Seed Drill in (Sowing Seeds, Foliar Feeding and Weed Control) Operations on the Wheat Fields at Some Egyptian Governorates
}

\author{
Hamdi Z. Abouleid ${ }^{1}$, Ahmed Osama Saad ${ }^{2}$, A. Y. Hammad ${ }^{3}$ \\ ${ }^{1}$ Prof. Dr. Plant Pathology Department, National Research Center (NRC), Cairo, Egypt \\ ${ }^{2}$ Prof. Dr. Field Crops Department, National Research Center (NRC), Cairo, Egypt
}

${ }^{3}$ Assistant Professor Researcher and International Senior + Agricultural, Soil and Marine Division, Agricultural Applications Department, National Authority for Remote Sensing \& Space Sciences (NARSS), Cairo, Egypt

\begin{abstract}
The process of seed dispersal considered the largest agricultural operations and the most widespread in its agricultural aviation aircraft in the United States, Canada and other countries. The sowing seeds wherewithal/ a method by Helicopter is optimal advantage and superior, especially in cases of small-scale seed dispersal, such as wheat, barley, rice, flax, sorghum. This method is also considered optimal when the desire for rapid agriculture to compensate for the delay in sowing date, as well as in agriculture in the uneven ground. Moreover, the seeding on the flat ground by aircraft has many advantages where they are scattering on the large areas speedy to avoid bad weather and get the best plant density gained from ground agriculture. The flow process of seeds from Helicopter and planted in processed soil for planting meticulously; as a result to equal of the grain weight with the absence of exotic materials. Once calibrated the device which responsible for the flow and the distribution of seeds in the Helicopter, It will function in the work is outweigh than any another unparalleled device; distinct in its accuracy and regularity; this is an excellent evidence as optimal methodological for the precision farming system. Now is available some sophisticated modern devices capable to scattering the seeds from the Helicopter in narrow lines, which adds to the process of seed dispersal by aircraft recipe great application. The current study provides a practical assessment in order to the testing efficiency of scattering seeds, foliar feeding and weed control process, using the Helicopter - Mi-2, on the fields crops; at Egyptian lands belonging to Public Authority for Agricultural Reclamation at Al Sharqia, Gharbia and Beheira Governorates. The scientific assessment of Sowing the Seeds, foliar feeding and weed control operations, using the Helicopter-Mi-2, on the fields crops; at various governorates.
\end{abstract}

Key words: Helicopter; seed drill; sowing seeds; foliar feeding; weed control; wheat; Egyptian Governorates

\section{Introduction}

Aerial seeding is often the largest cost associated with burned area emergency rehabilitation projects. The complexities involved in implementing safe and efficient aerial seeding operations demonstrate the need for a logical, planned approach for accomplishing needed work. If a project is not well-planned, opportunities exist for things to go wrong, the potential for accidents and injuries increases, and the probability of not accomplishing the work increases. In the haste of trying to get work done within short timeframes, one must ensure that critical tasks and/or responsibilities are not overlooked. Aerial seeding requires contracting assistance. It requires the purchase of often large amounts of seed and the use of specialized equipment to implement emergency prescriptions to stabilize watersheds. We must be able to secure these goods and services on short notice; and we must be able to organize to effectively and safely implement these kinds of projects. Regardless of size, aerial seeding projects can range from simple to very complex. Each can (and will present its own set of challenges. We must be able to assess and respond to these situations,[11]. Provincial Helicopters has become a true force in the application world of aerial seeding and much more. So in the world of spraying, we have expanded into forestry spraying as well as some agricultural and pesticide work,[13]. Air Tractor Inc. is a United States aircraft manufacturer based in Olney, Texas. Leland Snow founded the company in 1978 in order to manufacture a new agricultural aircraft derived from the $\underline{\mathrm{S}-2 \mathrm{~B}}$ aircraft (designed by his previous company Snow Aeronautical). Designated Model AT-300 Air Tractor, the new aircraft first flew in 1973. In 2004 the 2000th Air Tractor aircraft was delivered. Best Ag Plane for the Job, Large or Small: Air Tractor produces the world's most extensive product line of ag aircraft, with eight type-certified Air Tractor models in current production from which to choose. Whether the job is spraying, seeding, fertilizing, or firefighting, more operators choose Air Tractor because they get the most productive, highest quality and cost-effective ag planes available anywhere, at any price. And operators know they can rely upon Air Tractor's worldwide dealer network for service, parts and support,[1]. An agricultural aircraft is an aircraft that has been built or converted for agricultural use - usually aerial application of pesticides (crop dusting) orfertilizer (aerial topdressing); in these roles they are referred to as "crop dusters" or "top dressers". Agricultural aircraft are also used forhydroseeding. The most common agricultural aircraft are fixed-wing, such as the Air Tractor, Cessna Agwagon, Gippsland GA200, Grumman Ag Cat, PZL-106 KRUK, M-18 Dromader, PAC Fletcher, Piper PA-36 Pawnee Brave, Embraer EMB 202 Ipanema, and Rockwell Thrush Commander but helicopters are also used. Generally nearly every agricultural aircraft have piston or turboprop 


\section{International Journal of Science and Research (IJSR) \\ ISSN (Online): 2319-7064}

Index Copernicus Value (2013): 6.14 | Impact Factor (2015): 6.391

engines, the only known exception is the Polish PZL M-15 Belphegor, which was the only aircraft with a jet engine. Early use of aircraft in agriculture: Crop dusting with insecticides began in the 1920s in the United States. The first widely used agricultural aircraft were converted war-surplus biplanes, such as the De Havilland Tiger Moth and Stearman. After more effective insecticides and fungicides were developed in the 1940s, and aerial topdressing was developed by government research in New Zealand, purposebuilt agricultural fixed-wing aircraft became common,[12]. Establishing a cover crop by aerial broadcast. A big advantage of aerial seeding of cover crops is that more acres can be seeded in less time than with ground equipment. Aerial application also allows seeding to be done when it is physically impossible to use ground equipment, such as when crops are present, or the soil is too wet for regular equipment. Seeding, germination, and growth of cover crops can begin even before the existing crop has been harvested. This is especially important in areas where there is a very small window of opportunity between crop harvest and the end of the growing season. Waiting to seed a cover crop until after crop harvest may result in poor stand establishment due to cold temperatures or moisture stress. Aerial seeding is always more risky than drilling or incorporation of the seeds, so it's important to have the right soil surface and weather conditions at seeding time,[5]. 1. Why seed by air? 2. How do costs and results of aerial seeding compare to other methods? 3. What's the best time to seed? 4. What should seeding rates be by air? 5. Is an airplane or helicopter a better choice, and how do I find a pilot? [10]. Aerial seeding of winter wheat into soybeans just prior to soybean leaf drop is a practice that has been used in recent years as an alternative to conventional seeding. Seeding winter wheat in early to mid September increases winter survival and yield potential in most situations. However, factors such as wet soil conditions, labor and machinery restrictions, and delayed soybean harvest may prevent farmers from reaching this goal. Past experience by growers have resulted in both success and failure with aerial seeding. Research conducted from 1991 to 1994 at Arlington, Wisconsin compared aerial seeding winter wheat before and after soybean leaf drop with aerial or drill seeding after soybean harvest. Each of these methods were compared using two varieties (Merrimac and Cardinal), two seeding rates (40 and 60 seeds/sq. ft.) and two soybean row spacings ( 7 and 30 inch). None of the wheat survived in 1992, therefore results from three years are discussed here Conclusion: When seeding winter wheat following soybeans, aerial seeding immediately before soybean leaf drop is preferred over delayed aerial seeding times or drilling after soybean harvest. Conclusion: Adequate plant stands for maximum yields can be achieved by aerial seeding wheat at $40 \mathrm{seeds} / \mathrm{sq}$. ft. Aerial seeding rates do not need to be increased more than $15 \%$ over the currently recommended rates when drilling. Advantages of aerial seeding winter wheat into standing soybean are:1 -Earlier planting is possible (30 days). 2- Yields are higher than when planting after soybean harvest. 3 - Labor and equipment savings are possible . 4- Wheat is seeded in equidistant spacings. 5 - Early wheat growth can provide for erosion control. Disadvantages of aerial seeding winter wheat into standing soybean are: 1 - Little protection of wheat crown thus increasing chances of winter injury. 2 - Early seeding may result in higher disease incidence. 3 - Seed costs are 10-
$15 \%$ higher. 4 - Aerial seeding costs are \$10-15/acre. 5Success in stand establishment is more weather dependent,[8]. Aerial seeding of cover crop allowed more time for crop establishment and biomass accumulation in the fall and a stronger start in the spring. The fall-drilled cover crop produced less total biomass, but still established and overwintered acceptably. Though not determined statistically, corn yields in 2011 from plots that included cover crops, regardless of aerial seeding or drilling, were greater than corn yields from check plots that did not include cover crops, [3]. Foliar Feeding refers to the application of fertilizers to a plant's leaves. It is not a substitute for maintaining adequate levels of plant nutrients in the soil but can be beneficial in certain circumstances. Most commonly, it is recommended for alleviating specific micronutrient deficiencies. In recent years, products have been developed that contain growth hormones, natural Plant sugars, microorganisms and other ingredients. There is very little evidence that these products are especially effective,[9]. Foliar feeding, a term referring to application of essential plant nutrients to above-ground plant parts, has been documented as early as 1844 (21), when an iron sulfate solution was sprayed as a possible remedy for "chlorosis sickness." More recently, foliar feeding has been widely used and accepted as an essential part of crop production, especially on horticultural crops (21). Although not as widespread on agronomic crops, the benefits of foliar feeding have been well documented and increasing efforts have been made to achieve consistent responses (24),[3]. The Airport Technical Assistance Program (AirTAP), Today, agricultural aircraft operations remain a viable and important activity routinely conducted at Minnesota's airports. The issues previously raised are still relevant, and airport owners and operators are seeking to develop sustainable practices that ensure safe and environmentally responsible operations. In addition, many new resources are available from a variety of public agencies. The intent of the publication is to provide airport managers with a better understanding of agricultural aircraft operations and recommended practices for dealing with agricultural spraying operations, [4]. Application of plant seed to burned slopes by aircraft. Purpose: Aerial seeding, usually grasses but occasionally also legumes, is carried out to increase vegetative cover on a burn site during the first few years after a fire. It is typically done where erosion hazard is high and native plant seed bank is believed to have been destroyed or severely reduced by the fire. Seed is applied by fixed-wing aircraft or helicopter. Relative Effectiveness: Excellent-24\% Good-28\% Fair-28\% Poor$20 \%$ (Replies $=83$ ). Interviewees were almost evenly divided on the effectiveness rating of aerial seeding, with a slight majority regarding it as either "good" or "fair". Respondents in Regions 1, 4, and 6 were more likely to rate seeding "excellent" or "good" than respondents in Regions 3 and 5,[11]. Our objective is an economic comparative assessment between agricultural services instruments as real time management and navigation of precision farming using Air -Tractor and seed drill on the wheat fields at some Egyptian Governorates. Air-Ag., system such as aerial (seeding/seedling, foliar feeding and weed control) operations are the real time management and navigation of precision agriculture management. 


\section{International Journal of Science and Research (IJSR) \\ ISSN (Online): 2319-7064}

Index Copernicus Value (2013): 6.14 | Impact Factor (2015): 6.391

\section{Methodology}

The Mil Mi-2 (NATO reporting name Hoplite) is a small, lightly armored turbine-powered transport helicopter that could also provide close when armed with $57 \mathrm{~mm}$ rockets and a $23 \mathrm{~mm}$ cannon.

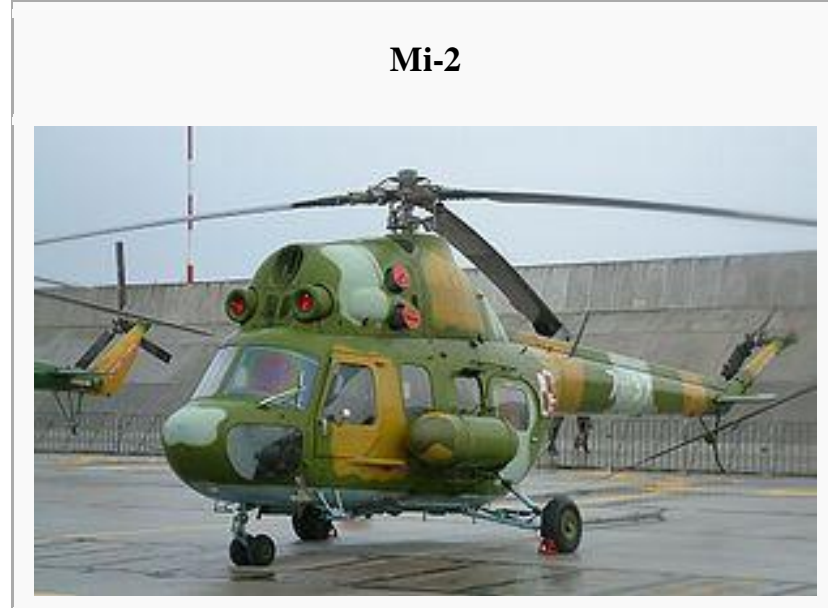

Figure 1: Polish Air Force Mi-2 at Krzesiny Air Base

\begin{tabular}{|c|c|}
\hline Role & Helicopter \\
\hline Manufacturer & PZL-Świdnik, Poland \\
\hline First flight & 22 September 1961 \\
\hline Introduction & 1965 \\
\hline Primary users & $\begin{array}{l}\text { Soviet Air Force } \\
\text { Polish Military } \\
\text { Aeroflot }\end{array}$ \\
\hline Produced & 1965-1998 \\
\hline Number built & 5,497 \\
\hline Developed from & Mil Mi-1 \\
\hline Variants & PZL Kania \\
\hline
\end{tabular}

General Specifications of the Helicopter - Mi-2; used in the scattering of seeds and other agricultural aviation business and services, the owner is Arab Agricultural Aviation Company-AGRICO-AGC:

1) Helicopter - Mi-2, Polish manufacturing, used in Eastern -Europe, the Commonwealth, some Middle East countries and African countries

2) Helicopter - Mi-2, utilizing in the agricultural spraying, seeding / fogging / transfer cargo / passenger transport / medical evacuation / some military purposes / in the training of pilots

3) A twin-engine jet vigorously 800 horsepower mechanically

4) The average speed of the Helicopter - Mi-2 is $155 \mathrm{~km} /$ $\mathrm{h}$

5) Maximum height is $4 \mathrm{~km}$

6) Over the flight distance of up to $250 \mathrm{~km}$ by the main tanks and $550 \mathrm{~km}$ with the loading of additional tanks.

7) The aviation with loading the sowing the Seeds tanks for 50 minutes

8) The capacity of the sowing the seeds tanks or spraying of the pesticides is $700 \mathrm{~kg}$ or 600 liters of chemical liquids
9) The width of the spraying fountain up to 30 meters for chemicals

10) The seeds type of appropriate and viable of the seeding operation such as wheat, barley, rice, trefoil, flax, sorghum, sesame, feed grain/ Seeds

11) The width of the spraying fountain during the seeding process is up to 40 meters.

12) Two outlets for the seeds

13) The average area could be cultivated with wheat 52.0003 Acres/ hour at a rate of $50 \mathrm{~kg}$ seeds / Acre

14) The average area could be cultivated clover 210.0012 Acres / hr at a rate of $10 \mathrm{~kg} / \mathrm{acre}$.

15) The average duration sortie air to the process of seeding is 20 minutes

16) The flow and the momentum rate of the wheat seed out of the plane during the seeding process is $34.5 \mathrm{~kg} / \mathrm{min}$

17) The speed seed flowing out of the plane is $80 \mathrm{~km} / \mathrm{h}$, [5].

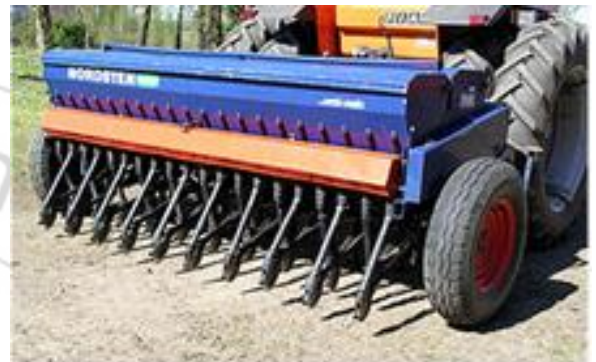

Figure 2: A sewing machine which uses the seed dril concept

A seed drill is a sowing device that positions seeds in the soil and then covers them. The seed drill sows the seeds at equal distances and proper depth. This ensures that the seeds also get covered with soil. This saves them from being eaten by birds. Before the introduction of the seed drill, the common practice was to plant seeds by hand. Besides being wasteful, planting was very imprecise and led to a poor distribution of seeds, leading to low productivity. Jethro Tull is widely thought of as having invented the seed drill though earlier the Sumerians used a single-tube seed drill, and the Chinese had also used a multi-tube seed drill. The use of a seed drill can improve the ratio of crop yield (seeds harvested per seed planted) by as much as nine times. In short, the seed drill can be described as a modern agricultural implement used for sowing seeds, [6].

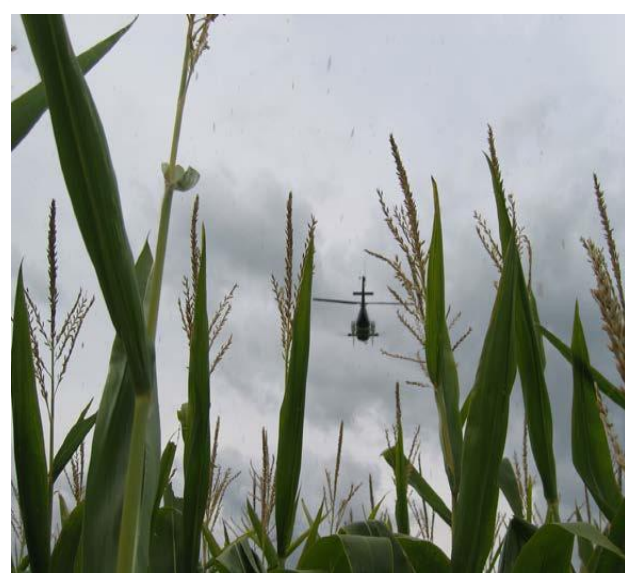

Figure 3: Helicopters can maneuver better in irregular fields

Our work is approaching to aerial seeding equipment fixed wing vs. rotary wing aircraft for seeding cover crops - which 


\section{International Journal of Science and Research (IJSR) \\ ISSN (Online): 2319-7064}

Index Copernicus Value (2013): 6.14 | Impact Factor (2015): 6.391

is best? Both types of aircraft are capable of quickly spreading seed above the crop canopy. Anecdotal evidence gives a slight advantage in cover crop establishment to helicopters, because the air turbulence from the blades shakes the crop canopy, preventing the seed from being caught on the leaves, and the downward pressure forces the seed onto the ground. Fixed-wing aircraft can carry heavier loads of seed and fly faster across the field. Helicopters are more maneuverable, and can do a better job on irregularlyshaped fields and along end rows and headlands. Optimum seed drop is from a height of 50 to 60 feet above the canopy. A third method of above-canopy seeding is a high clearance vehicle, such as a high - clearance sprayer. These vehicles are slower than aerial seeding and will cause some crop damage when turning at the end of a field. Some may not have enough clearance for tall crops like corn, and their use is limited by wet soil conditions. The advantages are: many farms now own or can rent this equipment; it is available during the best time for seeding cover crops; the farmer can operate the equipment himself; and it is may be less expensive than custom aerial seeding. The main criteria for choosing between types of will probably be cost of rental and availability of the equipment. However, delaying seeding in order to get the cheapest seeding method may mean poor establishment due to moisture conditions or shortened growing season. Timing of seeding is a crucial aspect of cover crop success, [7].

\section{Results and Discussion}

First, evaluate the processes of scattering seeds and weed control by Helicopter Mi-2 on the Wheat fields at Al Sharqia, Governorate:

Table 1: shows the contracted planted areas with weed control in its fields, and dates of cultivation and strains of wheat planted in agricultural reclamation areas at Al Sharqia,

Governorate

\begin{tabular}{|c|c|c|c|}
\hline $\begin{array}{c}\text { Egyptian } \\
\text { wheat } \\
\text { commercial } \\
\text { cultivars of } \\
\text { high-yield }\end{array}$ & $\begin{array}{c}\text { Sowing the } \\
\text { Seeds Date }\end{array}$ & $\begin{array}{c}\text { Acres } \\
\text { area }\end{array}$ & Region's local name \\
\hline GZ163 & 116 & 232.003 & Mansheya \\
Giza163 & $1993 / 11 / 20$ & & \\
\hline SKH69 & $1993 / 11 / 20$ & 70.0004 & Kafr Dnohia (Zagazig) \\
\cline { 2 - 4 } Sakha69 & $1993 / 11 / 20$ & 185.001 & Borden \\
\hline & & 487.003 & The total area \\
\hline
\end{tabular}

The real time and navigation of the precision farming data of sowing the seeds process using the plane:

- *Plane used is the Helicopter Mi-2.

- *The average height of the aircraft above the Earth's surface during the scattering of seeds is $5-10 \mathrm{~m}$.

- *The medium speed of the aircraft above the land's surface during the scattering of seeds: $60-80 \mathrm{~km} / \mathrm{h}$.

- The width of the spraying fountain during the seeding process is up to 40 meters.

- Wheat seed flow out of the plane during the planting rate is $34.5 \mathrm{~kg} /$ minute.

- The area which has been cultivated wheat during sorties flight duration of 20 minutes is 14.00008 Acres.

- The amount of wheat seed used in farming per-Acre by plane is $50 \mathrm{~kg}$ seeds / Acre. 5-cultivation services program for wheat:

A- At the beginning of the seedling: $100 \mathrm{~kg} /$ acre composting Super calcium phosphate.

B- After three weeks of the seed germination process/ seedling: $200 \mathrm{~kg} /$ acre fertilizer ammonium nitrate $23.5 \%$.

6-Weed control using the plane: After a month of the seed germination process/ seedling: spraying herbicide Bromenal liter pesticide / 20 liters of water rate; after a month of the seed germination process/ seedling.

7-Scientific assessment of the cultivated wheat area under the precision farming operations conducted by plane:

7-1: Estimating plant density of wheat per acre:

The plant density of wheat per acre was estimated per acre, the method for estimating by the number of developing wheat plants in samples area per square meter such as its called Leaf Area Index-(LAI), in several different places and trends randomly in the field, the number of replications estimate three replicates and the results were obtained as follows:

Bis1 $=1.024 .000$ plants / acre

Bis2 $=1.248 .000$ plants $/$ acre

Bis $3=1,600,000$ plants $/$ acre

The average plant density of wheat grown by plane = $1,292,667$ plants / acre which is considered high plant density. Some spots absent which free space is very limited plants have been observed.

2/7- The evaluation of the aerial spraying of the Anti-wheat weeds (Bromenal) pesticide:

It became clear from the preview; the areas sprayed by herbicide have nearly deserted of most the weeds that accompanying with wheat plants, except for a small percentage of grass such as Rumex dentatus, Ammi majus and Polypogen monspeliens.

3/7- Comparative analysis for the evaluation productivity of wheat grown by Helicopter, compared with its grown using Seed Drill at Mansheya village:

Table 2: Illustrates the productivity of wheat crop planted by plane compared with its grown using traditional methods at

Mansheya village located in Al Sharqia, Governorate.

\begin{tabular}{|c|c|c|c|c|}
\hline Cultivation method & $\begin{array}{c}\text { Grain } \\
\text { harvest } \\
\text { *Ardeb } \\
\text { / acre }\end{array}$ & $\begin{array}{c}\text { Hay } \\
\text { crop } \\
\text { Tons / } \\
\text { acre }\end{array}$ & $\begin{array}{c}\text { Weight } \\
100 \\
\text { grain } \\
\text { Per } \\
\text { grams }\end{array}$ & $\begin{array}{c}\text { Total } \\
\text { yield } \\
\text { Tons / } \\
\text { acre }\end{array}$ \\
\hline Helicopter - bis1 & 26.41 & 6.918 & 4.85 & 10.879 \\
\hline Helicopter - bis2 & 21.54 & 6.682 & 4.59 & 9.913 \\
\hline Average & 23.98 & 6.800 & 4.72 & 10.396 \\
\hline Seed Drill-bis1 & 23.52 & 4.355 & 4.82 & 7.883 \\
\hline Seed Drill-bis2 & 19.44 & 3.982 & 5.02 & 6.898 \\
\hline Average & 21.48 & 4.169 & 4.92 & 7.391 \\
\hline
\end{tabular}

* ID[1\&2]: *Ardeb: a unit of capacity used for dry measure in Egypt and neighboring countries, officially equivalent in Egypt to 5.62 U.S. bushels, but varying greatly in different localities. *Egyptian Ardeb $=150 \mathrm{~kg}$

The results indicated in Table 2 to surpass all crop wheat (Ardebs / acre), as well as straw yield (tons / acre), subsequently outweigh of the total yield, with no significant difference of 100 wheat grains / gm, in cultivated areas by Helicopter comparative to their counterparts cultivated by Seed Drill. The results averages of the method planting by Helicopter were as follows: 23.98 ardebs of wheat grains, 6,800 tons of straw and thus total is 10.396 tons crop per 


\section{International Journal of Science and Research (IJSR) \\ ISSN (Online): 2319-7064 \\ Index Copernicus Value (2013): 6.14 | Impact Factor (2015): 6.391}

acre; vs. 21.48 ardebs of wheat grains, 4.169 tons of straw, and thus 7.391 tons per acre crop of the Seed Drill method. The reason for the superiority of grain crop and the straw/ hay when follow the method of planting by Helicopter to the regularity in the distribution of plants, leading to increased plant density. Also due to the slight increase in 100 wheat grains / gram weight, as evidence of the size of a grain of wheat- Grains resulting from the machine cultivation/ Seed Drill from those cultivated by Helicopter, to the existence of a reverse proportionality between the amount of the crop and the size of the resulting grain. It is noted in economic terms that the quantity of seeds used to planting/ cultivation by the Helicopter is $50 \mathrm{~kg}$ per acre while it is $60 \mathrm{~kg}$ per acre in the case of cultivation by Seed Drill.

Secondly, the foliar feeding assessment process by Helicopter Mi-2 on the Wheat fields at El- Gharbiya Governorate, Egypt:

1) Location: Alragdih village / Tanta Directorate.

2) Crop and cultivated varieties contracted to foliar feeding by Air Tractor is wheat -Sakha -69 .

3) The contracting authority: Agrarian Reform Directorate in Tanta - El-Gharbia Governorate, Egypt.

4) The foliar feeding area fertilized by Helicopter was 3440.0192 .

5) The foliar fertilization date by Helicopter was 1994/11/16.

Table 3: Comparative analysis of the wheat crop productivity, after foliar fertilization process, by Helicopter Mi-2 in return for the results of the crop fertilized by Seed Drill, at Alragdih village, Tanta Directorate, El- Gharbiya Governorate, Egypt

\begin{tabular}{|c|c|c|c|c|}
\hline $\begin{array}{c}\text { The cultivation operations by Helicopter Mi-2 and } \\
\text { Seed Drill }\end{array}$ & $\begin{array}{c}\text { Grain harvest } \\
\text { Ardebs / acre }\end{array}$ & $\begin{array}{c}\text { Hay crop } \\
\text { Tons / acre }\end{array}$ & $\begin{array}{c}100 \text { grains wheat } \\
\text { per gram }\end{array}$ & $\begin{array}{c}\text { Total yield } \\
\text { Tons / acre }\end{array}$ \\
\hline Seed Drill cultivation + fertilization by plane R1 & 18.03 & 6.973 & 4.38 & 9.718 \\
\hline Seed Drill cultivation + fertilization by plane R2 & 16.25 & 4.547 & 4.83 & 6.985 \\
\hline Average & 17.14 & 5.760 & 4.61 & 8.352 \\
\hline Seed Drill cultivation only R1 & 14.13 & 4.318 & 4.85 & 6.463 \\
\hline Seed Drill cultivation only R2 & 13.95 & 4.350 & 4.90 & 6.443 \\
\hline Average & 14.04 & 4.334 & 4.88 & 6.453 \\
\hline $\begin{array}{c}\text { The differences between the foliar feeding results } \\
\text { using the plane and Seed Drill }\end{array}$ & 3.10 & 1.426 & $0.27-$ & 1.899 \\
\hline
\end{tabular}

The resulting increase of foliar fertilizing cultivation using Air Tractor Technology due to effect compound foliar fertilizer "Butasin" content on $3 \%\left(\underline{\mathrm{K}_{2}} \underline{\mathrm{O}}\right)$ and Super fertilizer triple superphosphate $\mathrm{P} 2 \mathrm{O} 5 \% 8$, and access to wheat plants in the areas that have been fertilized by plane, As for the micro-droplets of fertilizer solution and Emitted from the spraying device in the plane the ability to coverage the surfaces of the leaves and shoots of wheat plants. It is known that the element potassium significant role in increasing the store protein movement in the stock and encourage transfer of nitrogenous compounds towards the wheat grain. It is understood that a great role of potassium element to increase the protein movement, stored in the leaves and encourages transfer of nitrogenous compounds towards the wheat grain. Moreover, by the adding potassium through the wheat shoot is a great importance in the wheat crop, it has been proven potassium deficiency in the heavy land and it is characterized by poor drainage this leads to lack of oxygen and increased carbon dioxide formation around the roots of wheat plants in those territories.
6) The foliar fertilization techniques of wheat using the Helicopter and Seed Drill.

7) The farming operation implemented by plane: Foliar fertilizer using the foliar compost "Butasin " content on $3 \%\left(\underline{\mathrm{K}}_{2} \mathrm{O}\right)$ and Super fertilizer triple superphosphate P2O5 \%8, spraying; after two months of cultivation/ seeding at the rate of 1 liter foliar fertilizer per 10 liters of water.

8) The evaluation productivity of wheat crop after the foliar fertilization process, clarify the results in Table 3, superiority of both grain and straw yield, subsequently outweigh of the total yield, with the lack of a significant difference in the 100 grains / gram weight. by comparison, in the fertilized areas by Helicopter than the counterpart fertilized by Seed Drill. the results of plantings fertilized by plane the output averages were 2.571 tons of grain, 5.76 tons of straw, 8.352 tons total crop, vs. 2.106 tons of grain and 4.334 tons of straw therefore 6.453 tons total crop of the plantations fertilized by Seed Drill.

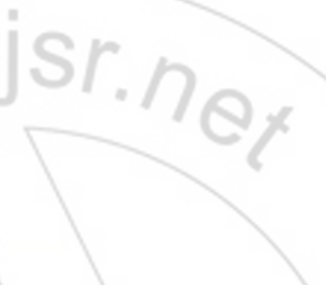

Thirdly, the assessment processes of scattering seeds and foliar feeding by the Helicopter Mi-2, on wheat fields at Beheira Governorate, Egypt:

1) The Contracting Authority: Agrarian Reform Damanhour Directorate - Beheira Governorate, Egypt.

2) Operations seeding contracted to conduct the plane:

a) Sowing seeds of wheat different strains in different locations of the Governorate

b) Foliar fertilizing for wheat planted areas by Air Tractor

3) The zones and areas which contractor on cultivated by Air Tractor for various strains of wheat and the cultivation dates in each region, , as in the Table (4) 


\section{International Journal of Science and Research (IJSR) \\ ISSN (Online): 2319-7064 \\ Index Copernicus Value (2013): 6.14 | Impact Factor (2015): 6.391}

Table 4: shows the regions, areas, the cultivation dates and strains of wheat planted by Air Tractor

\begin{tabular}{|c|c|c|c|}
\hline Region & $\begin{array}{c}\text { The area } \\
\text { per acre }\end{array}$ & cultivation dates & Wheat strains \\
\hline Damanhour & 100.001 & $1993 / 11 / 14$ & SKH69 Sakha69 \\
\hline Abu Matamir & 684.004 & $1993 / 11 / 29 ، 28 ، 17$ & SKH8 Sakha8 \\
\hline Nubaria & 67.000 & $1993 / 11 / 17$ & SKH8 Sakha8 \\
\hline Abu Hummus & 180.001 & $1993 / 11 / 23$ & \\
\hline Aloavadah & 36.000 & $1993 / 11 / 15$ & SKH69 Sakha69 \\
\hline Delengat & 38.000 & $1993 / 11 / 15$ & SKH69 Sakha69 \\
\hline Jabbars & 102.001 & $1993 / 11 / 20$ & SKH69 Sakha69 \\
\hline $\begin{array}{c}\text { Etay El } \\
\text { gunpowder }\end{array}$ & 226.001 & $1993 / 11 / 13.15$ & SKH69 Sakha69 \\
\hline Reservoir & 400.002 & $1993 / 11 / 16 ، 18$ & GZ163 Giza163 \\
\hline Total & 1833.010 & \multicolumn{3}{|l}{} \\
\hline
\end{tabular}

*1 Egyptian Feddan $=0.4047$ Hectares $=1.000$ Acres

*1 Hectares $=2.471$ Acres

4- Foliar feeding data of wheat areas that have been implemented by Air Tractor: It was sprayed using foliar fertilizer "Multi Micro" After seven weeks of cultivation, the fertilization rate by Aerial spraying, As follows: 10 liters / 500 liters of water is enough to spray 50 acres. Foliar fertilizer contains micro elements iron, copper, zinc, manganese addition of sulfur.

Table 5: The Plant density and the productivity of wheat crop planted and fertilized by Helicopter Mi-2, subsidiaries of Arab Company for Agricultural Aviation at Village reservoir facility, Beheira Governorate, Egypt

\begin{tabular}{|c|c|}
\hline Statement & Appreciation \\
\hline cultivated area by plane in the village & 400 acres \\
\hline Date scattering seeds by plane & $1993 / 11 / 16 ، 18$ \\
\hline wheat strain grown by plane & GZ163 Giza163 \\
\hline The number of plants developing per acre planted by plane & 720,000 plants / acre \\
\hline Average of number new seedlings of wheat grown by plane & $7.5(5-10)$ new seedlings of plant \\
\hline Average of number new seedlings of wheat per acre planted byplane & 5400000 new seedlings of plants /acre \\
\hline The average of grain yield per acre planted by plane & 18.24 Ardebs / acre \\
\hline Average of straw yield per acre planted by plane & 5.17 tons / acre \\
\hline Average of total yield (grain + straw) per acre planted by plane & $6,9,7$ tons / acre \\
\hline
\end{tabular}

Fourthly, a historical perspective and overall assessment from the current and previous results to scattering seeds, foliar fertilizing and weed control using the "Helicopter" operations in the Arab Republic of Egypt:

Table 6: the statement of scattering seeds and foliar fertilizing and weed control using Air Agriculture Services and its operations carried out in the Arab Republic of Egypt, starting from 1986 to the present study.

\begin{tabular}{|c|c|c|c|c|c|c|c|}
\hline Governorate & Region & season & $\begin{array}{c}\text { Cultivation } \\
\text { method }\end{array}$ & $\begin{array}{c}\text { Wheat } \\
\text { Strains }\end{array}$ & $\begin{array}{c}\text { Grain harvest } \\
\text { Ardebs/acre }\end{array}$ & $\begin{array}{c}\text { Straw yield } \\
\text { tons /acre }\end{array}$ & $\begin{array}{c}100 \text { wheat grain weight Per } \\
\text { grams }\end{array}$ \\
\hline Kafr el-Sheikh & Tayvh & $89 / 88$ & Helicopter & Sakha69 & 13.15 & 7.95 & 5.15 \\
\hline & Hamraui & $89 / 88$ & Helicopter & Giza163 & 12.40 & 6.02 & 5.01 \\
\hline & & & Seed Drill & Giza163 & 10.55 & 6.13 & 4.98 \\
\hline Al Sharqia & Ezbet Borden & $89 / 88$ & Helicopter & Sakha69 & 21.12 & 7.94 & 5.01 \\
\hline & Mansheya & & Seed Drill & Sakha69 & 17.22 & 11.26 & 4.06 \\
\hline & Almatmdip & $94 / 93$ & Helicopter & Giza163 & 23.98 & 6.8 & 4.72 \\
\hline & & & Seed Drill & Giza163 & 21.48 & 4.17 & 4.92 \\
\hline Gharbia & Qutour & $89 / 88$ & Helicopter & Sakha69 & 11.11 & 5.55 & 4.97 \\
\hline & & & Seed Drill & Sakha69 & 6.66 & 2.60 & 5.02 \\
\hline & Alragdih & $98 / 88$ & Helicopter & Sakha69 & 8.06 & 4.45 & 5.22 \\
\hline & & & & Sakha69 & 4.44 & 4.85 & 4.68 \\
\hline
\end{tabular}

As it is shown in the Table (6) the scattering seeds, foliar fertilizations process and weed control by Helicopters in Egypt has begun by Agricultural aviation squadron have begun with the Egyptian Air Force in 1986, it has been cultivating sorghum 150 acres on 6 October farm at Noubarya owner of the armed forces, then followed the Arab Company for Agricultural Aviation in many areas located in several Governorates. It observed that since that date, it has been planted, fertilized and control of weeds in an area of up to 628,876 acres, including 34,851 acres were planted by aircraft of wheat seed, alfalfa, flax and sorghum crops, Table 6 also shows that he has been planting new strains of wheat such as Sakha8, Sakha16, and Sakha61, Sakha69, and Giza163 by Helicopters, in several Governorate such as Kafr el-Sheikh, Al Sharqia,, Gharbia and Beheira, Governorates, as well as in The new reclamation areas such as Noubarya and El Gabal El Asfar Village, it is clear un Table (6) of the studies conducted by the research team on the scattering seeding by plane operations in the areas described in the Table (6) clear can be seen clearly outweigh the method cultivation of wheat seed by the Helicopter Mi-2, than ground conventional agriculture machine such as the Seed Drill.

\section{Conclusion}

Perhaps outweigh the method cultivation by Air AG., leads to increase the grain yield of wheat, comparing with farming by contrivance Seed Drill machine, which ranged from 1.85 ardebs increase in yield per acre at Hamraoui area of Kafr El-Sheikh- Governorate, 4.5 ardebs increase in yield per acre at the Almatmdip region, Gharbia- Governorate. Due to the 


\section{International Journal of Science and Research (IJSR) \\ ISSN (Online): 2319-7064}

Index Copernicus Value (2013): 6.14 | Impact Factor (2015): 6.391

cultivation of seeds is equal depth by Air Ag specializes. As a result, flowability of the plane at a steady rate [unified flow velocity for all seeds], subsequently, It leads to germination increase and distribution irregular of plants in the area unit. It is shown by estimating plant density of wheat per acre in these studies. on the way agriculture machine underline, which ranged between 1.85 ardebs increase in yield per acre in Hamraoui area of Kafr El-Sheikh governorate, 4.5 ardebs increase in yield per acre in Almatmdip area Gharbia Governorate - is due to equal the depth of planting seeds plane due to the flow of the plane at a steady rate and the speed and flow of each one of seeds, which germinate Maaada to increase the regularity of the distribution of plants in the space, which is shown by estimating plant density of wheat per acre in the studies. This large increase in the yield of wheat grain, which accounted for more than half a ton harvest grain and straw in the acre, In some areas planted by Helicopter Mi-2, This gives an indication of economically very important as it will result in the cultivation of strains wheat in the north-west coast or in the Sinai or on the Lake shore of higher dam or other arable land, as if they were cultivation by aerial application services / Air Ag., specializes, with the provision of competence, experience, proficiency and cutting-edge technology. The results obtained are also giving signs of success in the possibility of cultivation of vast new areas with scarce manual labor or that it is difficult to find a sufficient number of mechanical farming machinery and where also increase the economic cost of two employments manual and mechanical agricultural service even if they were available in the two cases. These results give an accurate vision to Agricultural Aviation Services, as real time and navigation of the precision cultivation management systems, this is the most important features economic, practical and artistic optimized for use in the scattering of seeds in these areas, In terms of execution speed and accuracy performance, the successful use of agricultural aviation operations on wheat fields, it supports planting seeds, to other air agricultural services operations, especially foliar fertilization and weed control associated with wheat during periods of growth, It is characterized by foliar fertilization process by "Mi -2" helicopters, easily conducting and cheaper costs, that reflux to the unequal distribution of the flow as micro-droplets spraying tiny solution, to cover the wheat growing areas, which reduces the cost of fertilization per unit area compared with the traditional methods of foliar fertilization by mechanical ground spraying. Moreover, the weed control accompanying the planting wheat, conducted by plane more easily in the wheat fields with large areas for the reasons mentioned earlier in the Foliar fertilization, addition to the inability to get rid of those weeds mechanically, except using motors ground spraying, which are difficult to use in large areas planted wheat.

\section{References}

[1] Air Tractor website, accessed 07 Feb 2008. Air Tractor, From Wikipedia, the free encyclopediahttps://en.wikipedia.org/wiki/Air Tractor\# cite note-1 Air Tractor Explained http://everything.explained.today/Air Tractor/Settle For Nothing Less Than The Besthttp://www.airtractor.com/
[2] Carlson, S. and Gailans, S., 2013, Aerial seeding versus drill seeding cover crops: Updated with corn yield observations, PRACTICAL FARMERS OF IOWA, Funding By: Sustainable Agriculture Research and Education Program (SARE), Cooperators: McGrew Brothers' Farm - Emerson. www.practicalfarmers.org http://practicalfarmers.org/wp-

content/uploads/2014/01/Aerial-seeding-versus-drillseeding-cover-crops-Updated-with-corn-yieldobservations-2013.pdf

[3] Curley S.; Curley R. D.; Hart E.; Hecht R. ; Don J. ; Menghini J.; Pohlman K.; and Buren N. V. , 1994, FOLIAR NUTRITION: FOLIAR APPLIED PLANT NUTRITION Midwest Laboratories, Inc., Omaha, https://www.midwestlabs.com/wpcontent/uploads/2013/08/foliar_nutrition.pdfNE.

[4] Minnesota Airport Technical Assistance Program (AirTAP), 1995, Agricultural Aircraft Operations on Municipal Airports, A Guidebook for Municipal Airport Managers, Center for Transportation Studies (CTS) University of Minnesota 511 Washington Ave. S.E. Minneapolis, MN $55455 \quad 612-626-1077$ www.airtap.umn.edu The University of Minnesota is an equal opportunity educator and employer. This publication is available in alternative formats by calling 612-626-1077. Printed on recycled paper with 10 percent postconsumer waste.http://www.airtap.umn.edu/publications/factsheets /toolkit/documents/agriculturalaircraft.pdf

[5] Męczykowski L., Mi-2. Polski hoplita, 2009, "Histmag.org", 25 czerwca.Благовестов А. - Каталог современного оружия ведущих странпроизводителей $M$ u-2, "avia.cybernet.name" Mil Mi-2, From Wikipedia, the free encyclopediahttps://en.wikipedia.org/wiki/Mil_Mi-

2\#cite_note-1

[6] Needham J.; (1986); Temple, Robert; The Genius of China: 3000 years of science, discovery and invention. New York: Simon and Schuster $<$ Based on the works of Joseph Needham $>$ Seed drill, From Wikipedia, the free encyclopediahttps://en.wikipedia.org/wiki/Seed_drill

[7] NRCS, Iowa , 2010, Aerial Seeding of Cover Crops, Agronomy \# 36, NOTES Iowa State Office, TECHNICAL NOTES U.S. Department of Agriculture, Natural Resources Conservation Service, Des Moines. http://www.nrcs.usda.gov/Internet/FSE_DOCUMENTS/ stelprdb1167304.pdf

[8] Oplinger, S. E., 1994, Aerial Seeding of Wheat, Soybean and Small Grains, AGRONOMY DEPARTMENT 1575 Linden Drive University of Wisconsin-Madison 53706 608-262-1391 (C) 2004 Board of Regents of the University of Wisconsin System, doing business as the Division of Cooperative Extension of the University of WisconsinExtension.http://www.coolbean.info/pdf/small_grains/li brary/grain_production/aerial_seeding_of_wheat.pdf

[9] Pettinelli D., 1914, FOLIAR FERTILIZATION, Soil Nutrient Analysis Laboratory; 6 Sherman Place, Unit 5102, Storrs, CT 06269-5102 Union Cottage, Depot Campus, Mansfield. Issued in furtherance of Cooperative Extension work, in cooperation with the U.S. Department of Agriculture, Gregory J Weidemann, Director, Cooperative Extension System, University of 


\section{International Journal of Science and Research (IJSR) \\ ISSN (Online): 2319-7064}

Index Copernicus Value (2013): 6.14 | Impact Factor (2015): 6.391

Connecticut, Storrs. The Connecticut Cooperative Extension System is an equal opportunity employer and program provider. To file a complaint of discrimination, write USDA, Director, Office of Civil Rights, Room 326-W, Whitten Building, Stop Code 9410, 1400 Independence Avenue, SW, Washington. http://www.soiltest.uconn.edu/factsheets/FoliarFertilizati on.pdf

[10] Scott, J., Aerial Seeding Cover Crops: Answers to 5 Most-Asked Questions, "Timing is the big advantage to aerial seeding. You give the seed a chance to start growing early in the fall.' , Cover Crops ANSWERS \#1, one in a series giving you solid, dependable guidance from cover crops veterans, Published by Three Rivers Ag Consulting Cresco, Iowa. www.threeriversagconsulting.com http://threeriversagconsulting.com/wpcontent/uploads/2014/08/Aerial-Seeding-FactSheetFINAL-3.pdf http //:

[11]Aerial Seeding - Planning and Implementation http://www.fws.gov/fire/ifcc/esr/Treatments/arealseedingi.htm

[12] Agricultural aircraft, From Wikipedia, the free encyclopedia https://en.wikipedia.org/wiki/Agricultural_aircraft

[13] Spraying \& Seeding http://www.provincialhelicopters.ca/spray.html *ID:

*1. Ardeb: a unit of capacity used for dry measure in Egypt and neighboring countries, officially equivalent in Egypt to 5.62 U.S. bushels, but varying greatly in different localities.http://www.thefreedictionary.com/ardeb

*2. Egyptian Ardeb $=150 \quad \mathrm{~kg}$ https://ar.wikipedia.org/wiki/\%D8\%A5\%D8\%B1\%D8\%AF $\% \mathrm{D} 8 \% \mathrm{~A} 8$ 